Assessment of red clover (Trifolium pratense L.) productivity in environmental stress

Procjena proizvodnoga potencijala crvene djeteline (Trifolium pratense $\mathrm{L}$.) u uvjetima okolišnoga stresa

Tucak, M., Popović, S., Čupić, T., Krizmanić, G., Španić, V., Meglič, V., Radović, J.

Poljoprivreda/Agriculture

ISSN: $1848-8080$ (Online)

ISSN: 1330-7142 (Print)

http://dx.doi.org/10.18047/poljo.22.2.1

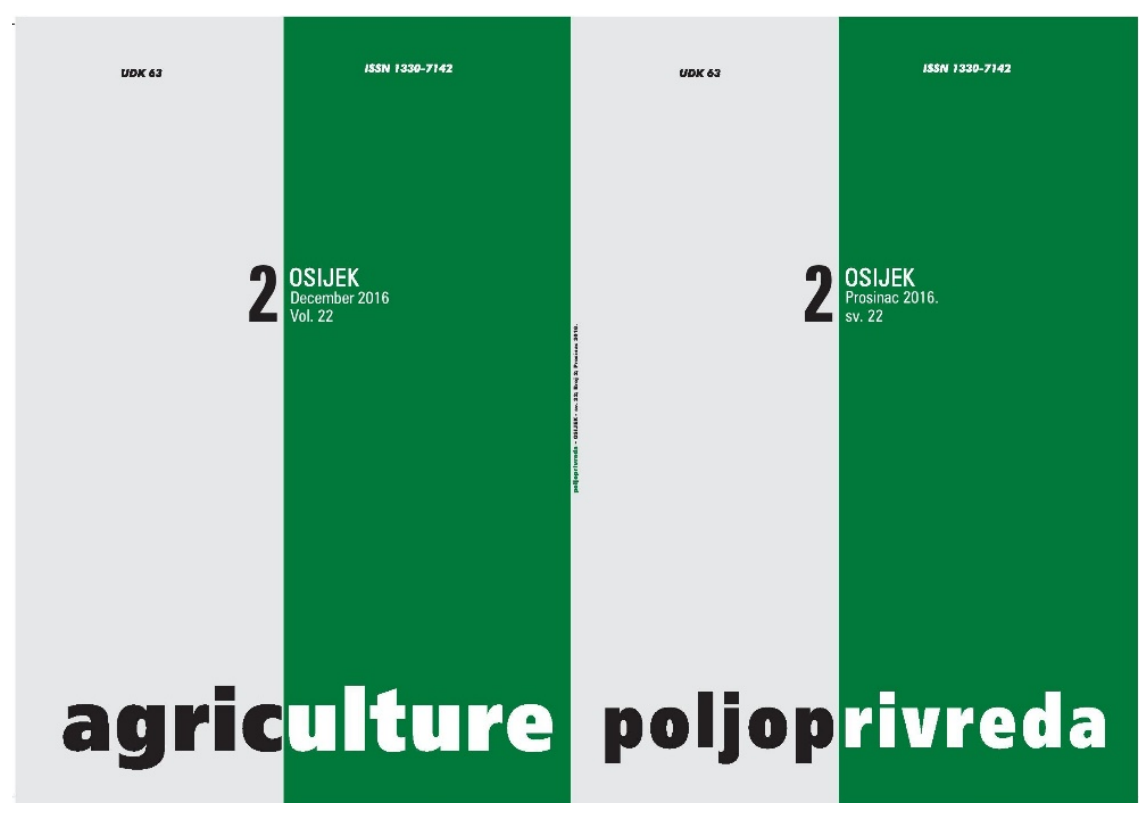

Poljoprivredni fakultet u Osijeku, Poljoprivredni institut Osijek

Faculty of Agriculture in Osijek, Agricultural Institute Osijek 


\title{
ASSESSMENT OF RED CLOVER (TRIFOLIUM PRATENSE L.) PRODUCTIVITY IN ENVIRONMENTAL STRESS
}

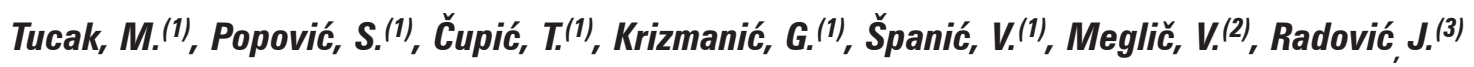

Original scientific paper

Izvorni znanstveni članak

\begin{abstract}
SUMMARY
The frequency of extreme climatic events has increased due to global climate change. The objectives of this research were to investigate the influence of climatic conditions (precipitation and temperature) on productivity of red clover cultivars and populations with a different genetic background and to identify those with high forage yield potential in environmental stress. Twenty-three red clover cultivars and populations of different geographical origin were studied during two consecutive growing seasons 12012 - extremely dry weather conditions, 2013 - humid weather conditions) at the Agricultural Institute Osijek, Croatia. A field experiment was performed as a randomized block design with three replicates. Green mass and dry matter yield and plant height were measured in both growing seasons, whereas the seed yield was determined in the first year only. Results indicated the stability or adaptability of evaluated red clover cultivars and populations to a dry or humid weather production conditions. Croatian populations (CD-3, TP-2, TP-7) and cultivar Viva, Serbian cultivar K-17 and German cultivar Taifun exhibited the highest forage yield potential under both, dry and humid growing conditions and represent a valuable material to be used in red clover breeding programs dealing with tolerance to abiotic stress.
\end{abstract}

Key-words: red clover, cultivar, population, yield, climate change, environmental stress

\section{INTRODUCTION}

Red clover (Trifolium pratense L.) is an important forage legume in temperate regions because it is easy to cultivate due to high adaptability to acidic and humid conditions. Depending on the way of cultivation, red clover may be used as an arable crop, in a pure stand, in a mixture with companion grasses and as a renovation crop drilled into an existing perennial pasture (Kolliker et al., 2006; Dujmović Purgar et al., 2009; Hejduk and Knot, 2010; Ortega et al., 2014). Red clover has several benefits: it combines a high yield potential with low nitrogen input, because of the possibility of biological nitrogen fixation, with a good protein content and acceptable digestibility (Jakešova et al., 2011; Krawutschke et al., 2013; Leto et al., 2013; Yates et al., 2014).

Red clover is usually grown, under agro-ecological conditions of Croatia, for two to three years and harvested three to five times a year, and in pure stands it yields up to $65 \mathrm{t} \mathrm{ha}^{-1}$ of green mass and $15 \mathrm{t} \mathrm{ha}^{-1}$ of dry matter in the first growing seasons (Popović et al., 2011; Tucak et al., 2013). Beside the dependence of forage yield and quality of red clover on genetic potential of cultivars or populations, those two traits are also affected by biotic (pests, diseases), abiotic ( $\mathrm{pH}$, soil fertility and climatic conditions) and management (frequency and intensity of cutting and/or grazing) factors.

The frequency of extreme climatic events has increased due to global climate change (Vaseva et al., 2012; Kizekova et al., 2013; Harrison et al., 2014; Shanker et al., 2014). Environmental stresses are limiting factors for production of important agricultural crops worldwide (Gaspar et al., 2002; Roy et al., 2011;

(1) Ph.D. Marijana Tucak (mtucak@poljinos.hr), Ph.D. Svetislav Popović, Ph.D. Tihomir Čupić, Ph.D. Goran Krizmanić, Ph.D. Valentina Španić Agricultural Institute Osijek, Juzno predgradje 17, 31000 Osijek, Croatia, (2) Ph.D. Vladimir Meglič - Agricultural Institute of Slovenia, Hacquetova 17, 1000 Ljubljana, Slovenia, (3) Ph.D. Jasmina Radović - Institute for Forage Crops, 37251 Globoder, Kruševac, Serbia 
Dumanoğlu et al., 2014; Hussain et al., 2014). Numerous studies have shown that the global climate change led to a wide range of negative impacts on the environment and as well the yield of many field crops. According to $\mathrm{Li}$ et al. (2011) $25 \%$ of the world's agricultural land is under the influence of drought stress, limiting growth, development and productivity of many forage crops.

Climate changes, especially precipitation and temperature regimes, have a direct, often adverse, influence on the quantity and quality of field crop yields (Kovačević et al., 2013).

Therefore, the objectives of this research were to investigate the influence of climatic conditions (precipitation and temperature) on productivity of twenty-three red clover cultivars and populations with a different genetic background and to identify those with high forage yield potential in environmental stress.

\section{MATERIAL AND METHODS}

\section{Plant materials}

Twenty-three red clover cultivars and populations of different geographical origin were included in this study. Seven breeding and local populations (TP$1,2,3,4,7,8$ and CD-3) and cultivar Viva are the result of the Breeding program for perennial forage crops at the Agricultural Institute Osijek, Croatia. Other red clover material was obtained from the following plant breeding and seed science companies/institutes and a gene bank: Saatzucht Steinach GmbH \& Co KG, Germany (cultivars Lucrum, Nemaro, Taifun and Titus); Zagreb Bc Institute for Breeding and Production of Field Crops, Croatia (cultivar Nada); Institute for Forage Crops, Kruševac, Serbia (cultivars K-17 and K-39); Agricultural Institute of Slovenia, Ljubljana, Slovenia (cultivars Živa and Poljanka); DLF-Trifolium, Denmark (cultivar Amos); Deutsche Saatveredelung AG - DSV, Germany (cultivar Milvus); South Australian Medicago Genetic Resource Centre, SARDI, Waite Campus, Urrbrae, Australia (cultivars Redquin and Nosovskij 5, populations TP-5,6).

\section{Field establishment and experimental design}

A field experiment was set up during two consecutive growing seasons (2012-2013) at the Agricultural Institute Osijek, Croatia $\left(45^{\circ} 32^{\prime} \mathrm{N}, 18^{\circ} 44^{\prime} \mathrm{E}\right.$, altitude 90 m). In mid-March 2012, the seeds of red clover cultivars and populations were sown by hand in $1.2 \mathrm{~m} \times 6$ $\mathrm{m}$ plots consisting of 6 rows with a $20 \mathrm{~cm}$ row space and the seeding rate of $20 \mathrm{~kg} \mathrm{ha}^{-1}$. The experiment was a randomized block design with three replicates. No fertilization or chemical treatment with herbicides was used before sowing.

The plots were harvested once in 2012 (2 July) and three times in 2013 (21 May, 2 July and 8 August). The red clover cultivars and populations were cut at the flowering stage using a forage plot harvester (Hege Model 212, Wintersteiger AG, Germany) and weighed to within $\pm 0.1 \mathrm{~kg}$. For all cuts in the first and second growing seasons, green mass yield (GMY in $\mathrm{t} \mathrm{ha}^{-1}$ ) and dry matter yield (DMY in $\mathrm{t} \mathrm{ha}^{-1}$ ) per plot and plant height $(\mathrm{PH}$ in $\mathrm{cm})$ were determined. Samples of green mass (approximately $500 \mathrm{~g}$ ) were taken from each plot in all harvests in the first and second growing seasons. Samples were dried at $105^{\circ} \mathrm{C}$ for at least $48 \mathrm{~h}$ for dry matter (DM) determination. Plant height was measured on ten randomly selected stems from the middle row of each cultivar and the population in all plots. The yields of green mass and dry matter for each plot were determined by summing the biomass yields from each cut and calculated in $\mathrm{t} \mathrm{ha}^{-1}$.

In the 2012 growing season, extremely dry conditions after the first cut resulted in a very slow regrowth of red clover cultivars and populations. Experimental plots were not harvested and were left growing for evaluation of seed yield.

The seeds of each cultivar and population were harvested when $85 \%$ of red clover heads reached maturity. The harvest was performed by a precision combine harvester for small grain legumes (Wintersteiger Classic). The chemical desiccation was not applied. Seed yield was determined by harvesting the total amount of seed from each plot and calculated seed yield per hectare $\left(\mathrm{kg} \mathrm{ha}^{-1}\right)$.

\section{Weather conditions}

Average monthly temperatures and total monthly precipitation for the red clover growing seasons (MarchOctober) during the study period (2012-2013) and long-term average for the experimental site Osijek are presented in Table 1. (Source: Statistical Yearbook of the Republic of Croatia, 2013). In 2012 the average temperature during the red clover growing season was $2^{\circ} \mathrm{C}$ higher compared to the long-term average temperatures. Equally higher monthly average temperatures were recorded during 2012 (for July $3.5^{\circ} \mathrm{C}$ and for August $3.3^{\circ} \mathrm{C}$ higher) compared to long-term averages. In 2012 the total amount of rainfall during the growing season $(358.6 \mathrm{~mm})$, as well as in certain months, excluding May and October, was significantly lower compared to the long-term average values. This indicates that this was a year with stressful conditions caused by drought. In 2013, the variation of average monthly temperatures during the red clover growing season was less pronounced, compared to the longterm averages. In 2013 significantly more precipitation was recorded during the growing season $(597.1 \mathrm{~mm})$ in comparison to the long term-average $(467.8 \mathrm{~mm})$, and more precipitation was recorded in May and September (78.2 $\mathrm{mm}$ and $70.6 \mathrm{~mm}$, respectively) compared to the same months in long-term average. 
Table 1. Average monthly air temperatures and total monthly precipitation for the red clover growing seasons during the study period at the experimental site Osijek

Tablica 1. Srednje mjesečne temperature zraka i mjesečne količine oborina za vegetacijsko razdoblje crvene djeteline tijekom promatranog istraživanja na pokusnoj lokaciji Osijek

\begin{tabular}{|l|c|c|c|c|c|c|}
\hline & \multicolumn{3}{|c|}{$\begin{array}{c}\text { Average monthly air temperature }{ }^{\circ} \mathrm{C} \text { ) } \\
\left.\text { Srednja mjesečna temperatura zraka ( }{ }^{\circ} \mathrm{C}\right)\end{array}$} & \multicolumn{3}{c|}{$\begin{array}{c}\text { Total monthly precipitation (mm) } \\
\text { Mjesečna količina oborina (mm) }\end{array}$} \\
\hline Month / Mjesec & 2012 & 2013 & LTA / VP & 2012 & 2013 & LTA / VP \\
\hline March / Ožujak & 8.7 & 5.2 & 6.4 & 0.9 & 78.3 & 40.5 \\
\hline April / Travanj & 12.5 & 13.5 & 11.2 & 45.5 & 43.8 & 51.0 \\
\hline May / Svibanj & 16.9 & 17.2 & 16.7 & 93.7 & 137.4 & 59.2 \\
\hline June / Lipanj & 22.5 & 20.4 & 19.9 & 67.9 & 69.4 & 82.0 \\
\hline July / Srpanj & 24.8 & 23.7 & 21.3 & 47.8 & 37.9 & 66.3 \\
\hline August / Kolovoz & 24.1 & 23.5 & 20.8 & 4.0 & 63.3 & 61.9 \\
\hline September / Rujan & 18.9 & 16.1 & 16.5 & 32.3 & 121.6 & 51.0 \\
\hline October / Listopad & 12.1 & 13.6 & 11.1 & 66.5 & 45.4 & 55.9 \\
\hline $\begin{array}{l}\text { Average / total* } \\
\text { Prosjek / ukupno* }\end{array}$ & 17.5 & 16.6 & 15.4 & $358.6^{*}$ & $597.1^{*}$ & $467.8^{*}$ \\
\hline
\end{tabular}

LTA - long-term average (Osijek, 1971.-2000.) / VP - višegodišnji prosjek (Osijek, 1971.-2000.)

\section{Statistical analysis}

Statistical analysis was performed using CropStat version 7.2 statistical program (IRRI, 2009). All collected data were subjected to analysis of variance (ANOVA) to enable for the LSDs calculation. Fisher's protected LSD test was used at the 0.05 and 0.01 probability level to identify significant differences between mean values of cultivars/populations and years.

\section{RESULTS AND DISCUSSION}

Analysis of variance revealed significant cultivar/ population and year effect for all the traits in both growing seasons (Table 2, Figure 1). The seed yield of cultivars and populations (the trait analysed in the first year of investigation) varied considerably (Figure 2). Croatian populations TP-2 (22.98 tha-1 in 2012) and CD-3 (83.33 $\mathrm{t} \mathrm{ha}^{-1}$ in 2013) had the highest average green mass yield in both years of the investigation. The highest yields of dry matter had Croatian populations CD-3 (5.97 t hain 2012) and TP-7 (16.24 $\mathrm{t} \mathrm{ha}^{-1}$ in 2013). The highest value of the average plant height in both study years was recorded in population TP-2 $187.16 \mathrm{~cm}$ and 78.66 $\mathrm{cm}$, respectively, Table 2). In addition, cultivars K-17 (Serbia), Viva (Croatia), Milvus and Taifun (Germany) exhibited the highest values for all traits in both years. In the first year of our study, significantly lower average yields of green mass and dry matter (19.78 and $4.37 \mathrm{t}$ $\mathrm{ha}^{-1}$ ) were recorded compared to the yields in the second year (65.29 $\mathrm{t} \mathrm{ha}^{-1} \mathrm{GMY}$ and $13.96 \mathrm{t} \mathrm{ha}^{-1} \mathrm{DMY}$ ). The average height of the plants of all cultivars and populations of red clover was significantly higher in the first year compared to the second growing season $174.93 \mathrm{~cm}$ in 2012, $70.92 \mathrm{~cm}$ in 2013, Figure 1). 
Table 2. Average yields of green mass and dry matter (GMY, DMY) and plant height (PH) of red clover cultivars and populations investigated in 2012 and 2013 growing seasons

Tablica 2. Prosječni prinosi zelene mase i suhe tvari (PZM, PST) te visina biljaka (VB) proučavanih sorti i populacija crvene djeteline u 2012. i 2013. vegetacijskoj sezoni

\begin{tabular}{|c|c|c|c|c|c|c|c|}
\hline \multirow[b]{2}{*}{ Name / Ime } & \multirow[b]{2}{*}{$\begin{array}{l}\text { Country of origin / type / ploidy } \\
\text { Zemlja porijekla / tip / Ploidnost }\end{array}$} & \multicolumn{3}{|c|}{2012} & \multicolumn{3}{|c|}{2013} \\
\hline & & $\begin{array}{l}\text { GMY / } \\
P Z M \\
\mathrm{t} \mathrm{ha} a^{-1}\end{array}$ & $\begin{array}{c}\text { DMY / } \\
P S T \\
\mathrm{t} \mathrm{ha}^{-1}\end{array}$ & $\begin{array}{l}\mathrm{PH} / \\
V B \\
\mathrm{~cm}\end{array}$ & $\begin{array}{l}\text { GMY / } \\
P Z M \\
\mathrm{t} \mathrm{ha-1}\end{array}$ & $\begin{array}{c}\text { DMY / } \\
P S T \\
\mathrm{t} \mathrm{ha}^{-1}\end{array}$ & $\begin{array}{l}\mathrm{PH} / \\
V B \\
\mathrm{Cm}\end{array}$ \\
\hline LUCRUM & GER $/{ }^{*} \mathrm{C} / 2 \mathrm{x}$ & 16.25 & 4.41 & 68.66 & 60.34 & 14.05 & 59.38 \\
\hline NEMARO & $\mathrm{GER} / \mathrm{C} / 2 \mathrm{x}$ & 15.55 & 4.47 & 70.00 & 59.51 & 13.03 & 65.00 \\
\hline TAIFUN & $\mathrm{GER} / \mathrm{C} / 4 \mathrm{x}$ & 20.69 & 4.89 & 66.33 & 70.06 & 15.59 & 65.61 \\
\hline TITUS & $\mathrm{GER} / \mathrm{C} / 4 \mathrm{x}$ & 18.75 & 3.23 & 71.16 & 67.70 & 12.14 & 65.44 \\
\hline TP-1 & CR0/P/2x & 19.72 & 4.27 & 72.33 & 66.59 & 14.53 & 68.83 \\
\hline CD-3 & CR0/P/2x & 22.15 & 5.97 & 82.66 & 83.33 & 15.97 & 75.50 \\
\hline NADA & CRO/C/2x & 19.58 & 4.22 & 75.66 & 61.04 & 13.19 & 71.83 \\
\hline TP-2 & CRO/P/2x & 22.98 & 5.17 & 87.16 & 73.68 & 14.90 & 78.66 \\
\hline TP-3 & CRO/P/2x & 20.00 & 3.77 & 77.50 & 62.01 & 12.70 & 67.94 \\
\hline TP-4 & CRO/P/2x & 15.27 & 4.15 & 76.16 & 66.25 & 13.44 & 73.00 \\
\hline K-17 & $\mathrm{SRB} / \mathrm{C} / 2 \mathrm{x}$ & 22.01 & 4.70 & 82.33 & 66.73 & 14.63 & 76.44 \\
\hline K-39 & $\mathrm{SRB} / \mathrm{C} / 2 \mathrm{x}$ & 19.93 & 3.93 & 52.83 & 56.31 & 12.12 & 72.55 \\
\hline POLJANKA & SLO/C/2x & 19.23 & 3.69 & 77.33 & 61.66 & 12.92 & 70.22 \\
\hline ŽIVA & $\mathrm{SLO} / \mathrm{C} / 2 \mathrm{x}$ & 18.54 & 3.97 & 74.16 & 65.13 & 14.60 & 72.16 \\
\hline MILVUS & $\mathrm{GER} / \mathrm{C} / 2 \mathrm{x}$ & 21.45 & 5.48 & 75.83 & 68.12 & 14.65 & 74.66 \\
\hline REDOUIN & AUS/C/2x & 20.90 & 4.38 & 76.66 & 63.47 & 13.93 & 73.38 \\
\hline TP-5 & AUS/P/2x & 20.06 & 4.27 & 77.33 & 62.29 & 12.84 & 70.83 \\
\hline NOSOVSKIJ 5 & $\mathrm{RUS} / \mathrm{C} / 2 \mathrm{x}$ & 21.11 & 4.38 & 78.00 & 64.02 & 14.21 & 71.27 \\
\hline TP-6 & AUS/P/2x & 19.07 & 3.72 & 74.50 & 58.54 & 12.57 & 67.27 \\
\hline TP-7 & CR0/P/2x & 22.22 & 5.11 & 84.50 & 68.54 & 16.24 & 74.94 \\
\hline TP-8 & CR0/P/2x & 17.98 & 3.76 & 63.16 & 61.38 & 14.21 & 70.77 \\
\hline AMOS & $\mathrm{DK} / \mathrm{C} / 4 \mathrm{x}$ & 19.93 & 3.66 & 77.50 & 63.68 & 13.95 & 71.83 \\
\hline VIVA & CR0/C/2x & 21.52 & 4.88 & 81.66 & 71.25 & 14.73 & 73.61 \\
\hline \multirow{2}{*}{\multicolumn{2}{|c|}{ LSD 0.01 cultivar/population }} & 4.90 & 1.19 & 15.58 & 13.69 & 2.80 & 10.85 \\
\hline & & 3.61 & 0.88 & 11.46 & 10.07 & 2.06 & 7.98 \\
\hline
\end{tabular}

${ }^{*}$ Cultivar-C, Population-P / Sorta-C, Populacija-P

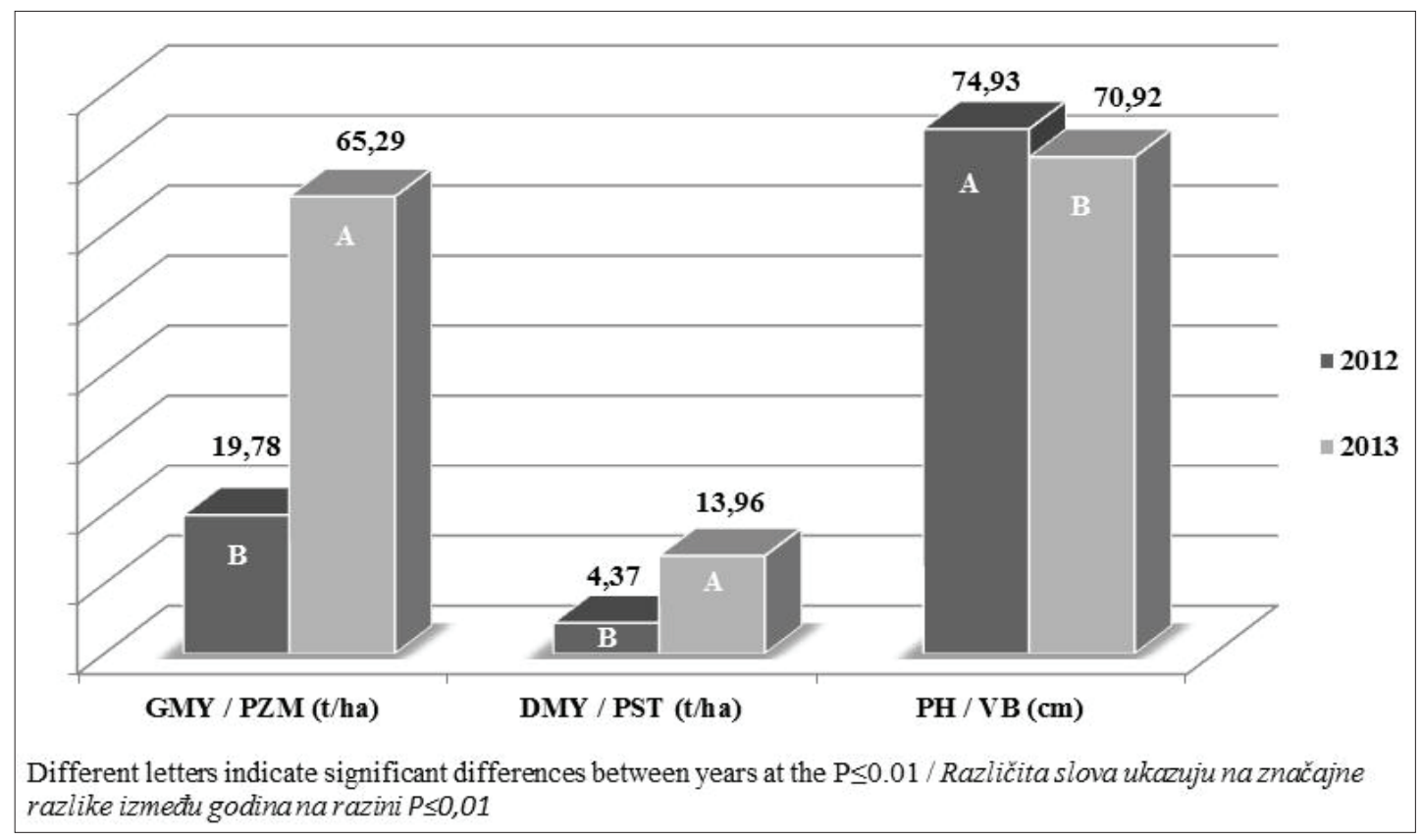

Figure 1. The average annual values for the studied traits investigated in both years (GMY - green mass yield, DMY - dry matter yield, PH - plant height)

Slika 1. Prosječne godišnje vrijednosti za svojstva promatrana u obje godine istraživanja (PZM - prinos zelene mase, PST prinos suhe tvari, VB - visina biljaka) 


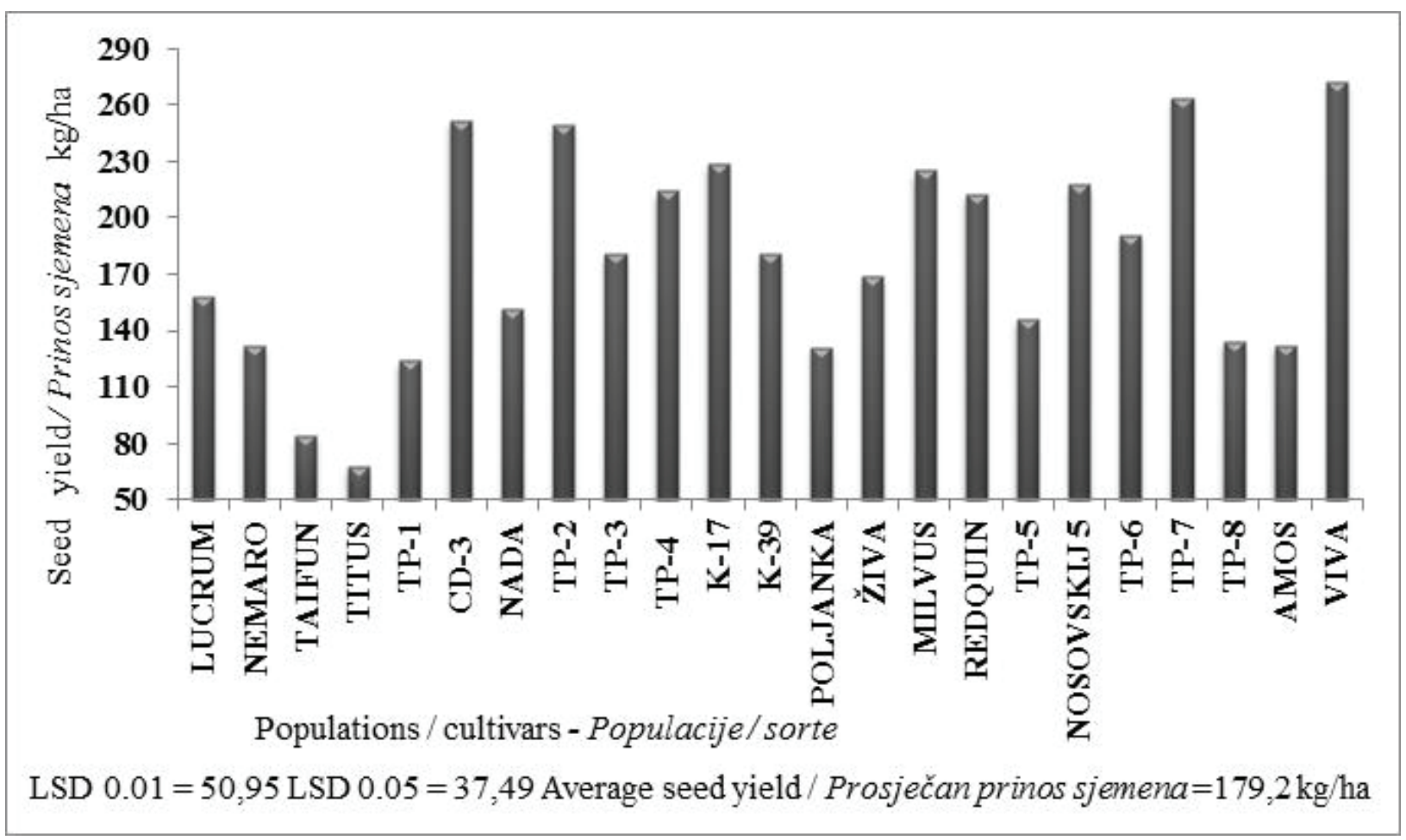

Figure 2. The average seed yield of red clover cultivars and populations in $\mathbf{2 0 1 2}$ growing season

Slika 2. Prosječan prinos sjemena sorti i populacija crvene djeteline u 2012. vegetacijskoj sezoni

During growing season, in the year of red clover establishment, extremely unfavourable weather conditions for plant growth and development were present. After the first cutting, dry season was prolonged (only $4.00 \mathrm{~mm}$ rainfall in August, Table 1) with increased temperatures. The resurgence of aboveground mass of red clover in such stressful conditions was very slow, the root system was not yet well developed and the ground water reserves were poorly available. Therefore, the plants in the experiment were not cut but left in open pollination to determine the yield of seed in the examined material, because further cutting could have led to exhaustion and decay of a large number of plants in most cultivars and populations.

High sensibility of red clover to stressful conditions caused by drought in 2012 resulted in low yields in all the cultivars and populations. Croatian populations and cultivars (TP 2,7; CD-3, Viva) and Serbian and German cultivars (K-17, Taifun) had higher tolerance to drought conditions observed by a higher productivity, even up to $35 \%$ higher yield, as compared to other tested materials. The high sensibility of red clover to environmental stress caused by drought was previously reported by Peterson et al. (1992), Sheaffer and Seguin (2009), Lang and Vejražka (2012), Gaudin et al. (2013) and Kizekova et al. (2013).

Seed yield was significantly different among studied cultivars and populations of red clover. The average seed yield was $179.2 \mathrm{~kg} \mathrm{ha}^{-1}$, which ranged from 68.13 $\mathrm{kg} \mathrm{ha}^{-1}$ (cultivar Titus) to $272.71 \mathrm{~kg} \mathrm{ha}^{-1}$ (cultivar Viva)
(Figure 2). The results of yield in this study are lower than the seed yield (482.4 $\mathrm{kg} \mathrm{ha}^{-1}$ ) reported by Barać et al. (2011), but are similar to results (seed yield up to $196 \mathrm{~kg} \mathrm{ha}^{-1}$ ) obtained by Doina and Bogdan (2011) by examining the influence of sowing system and year of harvest on the red clover seed yield.

The lower yields were obtained in 2012 although there were favourable weather conditions (less rainfall, increased temperature, the increased activity and abundance of insect pollinators) during flowering, pollination and fertilization of red clover for seed production. Several reasons could influence lower yields: reduced number of tillers due to drought conditions and weak formation of vegetative mass, less formed inflorescence and a large number of small and empty seeds.

Weather conditions with increased humidity during the vegetation season in 2013 were more favourable for the growth and development of red clover, which resulted in increased productivity of all cultivars and populations. Superior materials with high potential for forage yield in humid conditions were populations CD-3 (83.33 $\mathrm{t} \mathrm{ha}^{-1}$ which was $32 \%$ higher yield than the lowest green mass yield of $56.31 \mathrm{t} \mathrm{ha}^{-1}$ obtained by cultivar K-39), TP-2 and cultivars Viva and Taifun. Higher forage yield and quality properties in humid climatic conditions were reported by Leto et al. (2004) by examining the reaction of five diploid and one tetraploid cultivars of red clover to different agro-ecological conditions. 


\section{CONCLUSION}

Selecting red clover cultivars or populations with stability or adaptability to different environmental conditions is important due to their contribution to better tolerance of the crop to the future climate changes. Croatian populations (CD-3, TP-2, TP-7) as well as cultivar Viva, Serbian cultivar K-17 and German cultivar Taifun had the highest forage yield potential in both years under extreme weather conditions. Identified red clover cultivars and populations represent valuable genetic material to be used in red clover breeding programs aiming to improve the tolerance to abiotic stress and forage and seed yield.

\section{REFERENCES}

1. Barać, R., Duronić, G., Karagić, Đ., Vasiljević, S., Milošević, B. (2011): Effect of row spacing and seeding rate on seed and dry matter yield of red clover (Trifolium pratense L.). Field and Vegetable Crops Research, 48(1): 155-160.

2. Doina, S., Bogdan, I. (2011): Research on Trifolium pratense L. fertility in relation with the crop system. Agricultura, Agricultural Practice and Science Journal, 79(3-4): 124-128.

3. Dujmović Purgar, D., Koraca, K., Bertoša, J., Bolarić, S. (2009): Rasprostranjenost crvene djeteline (Trifolium pratense L.) u Hrvatskoj. Agronomski glasnik, 71(3): 225-236.

4. Dumanoğlu, H., Çelik, A., Büyükkartal, H.N., Dousti, S. (2014): Morphological and anatomical investigations on in Vitro micrografts of $\mathrm{OHxF} 333$ / Pyrus elaeagrifolia interstock / rootstock combination in pears. Tarim Bilimleri Dergisis/Journal of Agricultural Sciences, 20(3): 269-279.

5. Gaspar, T., Franck, T., Bisbis, B., Kevers, C., Jouve, L., Hausman, J.F., Dommes, J. (2002): Concepts in plant stress physiology application to plant tissue cultures. Plant Growth Regulation, 37(3): 263-285. doi: http://dx.doi.org/10.1023/A:1020835304842

6. Gaudin, A.C.M., Westra, S., Loucks, C.E.S., Janovicek, K., Martin, R.C., Deen, W. (2013): Improving resilience of northern field crop systems using inter-seeded red clover: a review. Agronomy, 3(1): 148-180. doi: http://dx.doi.org/10.3390/agronomy3010148

7. Harrison, M.T., Tardieu, F., Dong, Z., Messina, C.D., Hammer, G.L. (2014): Characterizing drought stress and traits influence on maize yield under current and future conditions. Global Change Biology, 20(3): 867-878. doi: http://dx.doi.org/10.1111/gcb.12381

8. Hejduk, S., Knot, P. (2010): Effect of provenance and ploidity of red clover varieties on productivity, persistence and growth pattern in mixture with grasses. Plant, Soil and Environment, 56(3): 111-119.

9. Hussain, M., Shah, K.N., Ghafoor, A., Kiani, T.T., Mahmood, T. (2014): Genetic analysis for grain yield and various morphological traits in maize (Zea Mays L.) under normal and water stress environments. The Journal of Animal and Plant Sciences, 24(4): 1230-1240.
10. IRRI, (2009): CropStat, version 7.2 for Windows 2009. International Rice Research Institute, Los Banos, Philippines.

11. Jakešova, H., Repkova, J., Hampel, D., Čechova L., Hofbauer, J. (2011): Variation of morphological and agronomic traits in hybrids of Trifolium pratense $x$ T. medium and a comparison with the parental species. Czech Journal of Genetics and Plant Breeding, 47(1): 28-36.

12. Kizekova, M., Tomaškin, J., Čunderlik, J., Jančova, L., Martincova, J. (2013): The yield stability and quality of legumes during two consecutive, extremely dry years. Agriculture/ Pol'nohospodárstvo, 59(4): 167-177. doi: http://dx.doi.org/10.2478/agri-2013-0015

13. Kolliker, R., Enkerli, J., Widmer, F. (2006): Characterization of novel microsatellite loci for red clover (Trifolium pratense L.) from enriched genomic libraries. Molecular Ecology Resources, 6(1): 50-53. doi: http://dx.doi.org/10.1111/j.1471-8286.2005.01133.x

14. Kovačević, V., Kovačević, D., Pepo, P., Marković, M. (2013): Climate change in Croatia, Serbia, Hungary and Bosnia and Herzegovina: Comparison the 2010 and 2012 maize growing seasons. Poljoprivreda/Agriculture, 19(2): 16-22.

15. Krawutschke, M., Kleen, J., Weiher, N., Loges, R., Taube., F., Gierus, M. (2013): Changes in crude protein fractions of forage legumes during the spring growth and summer regrowth period. The Journal of Agricultural Science, 151(1): 72-90. doi: http://dx.doi.org/10.1017/S002185961200024X

16. Lang, J., Vejražka, K. (2012): Yields and quality of forage legumes under imbalanced year precipitation conditions on south Moravia. Acta Universitatis Agriculturae et Silviculturae Mendelianae Brunensis, 60(6): 217-224.

17. Leto, J., Perčulija, G., Bošnjak, K., Kutnjak, H., Vranić, M., Čačić, I. (2013): Effects of genotype, inoculation and maturity stage at harvest on red clover (Trifolium pratense L.) yield and chemical composition. Mljekarstvo, 63(2): 98-108.

18. Leto, J., Knežević, M., Bošnjak, K., Mačešić, D., Štafa, Z., Kozumplik, V. (2004): Yield and forage quality of red clover (Trifolium pratense L.) cultivars in the lowland and the mountain regions. Plant, Soil and Environment, 50(9): 391-396.

19. Li, P., Chen, J., Wu, P. (2011): Agronomic characteristics and grain yield of 30 spring wheat genotypes under drought stress and nonstress conditions. Agronomy Journal, 103(6): 1619-1628. doi: http://dx.doi.org/10.2134/agronj2011.0013

20. Ortega, F., Parra, L., Quiroz, A. (2014): Breeding red clover for improved persistence in Chile: a review. Crop and Pasture Science, 65(11): 1138-1146. doi: http://dx.doi.org/10.1071/CP13323

21. Peterson, P.R., Sheaffer, C.C., Hall, M.H. (1992): Drought effects on perennial forage legume yield and quality. Agronomy Journal, 84(5): 774-779.

doi: http://dx.doi.org/10.2134/agronj1992.0002196200 $8400050003 x$

22. Popović, S., Tucak, M., Čupić, T. (2011): 'VIVA' - A new red clover (Trifolium pratense L.) cultivar. Sjemenarstvo, 28(3-4): 111-118. 
23. Roy, S.J., Tucker, E.J., Tester, M. (2011): Genetic analysis of abiotic stress tolerance in crops. Current Opinion in Plant Biology, 14(3): 232-239. doi: http://dx.doi.org/10.1016/j.pbi.2011.03.002

24. Shanker, A.K., Maheswari, M., Yadav, S.K., Desai, S., Bhanu, D., Attal, N.B., Venkateswarlu, B. (2014): Drought stress responses in crops. Functional and Integrative Genomics, 14(1): 11-22. doi: http://dx.doi.org/10.1007/s10142-013-0356-x

25. Sheaffer, C.C., Seguin, P. (2009): Kura clover response to drought. Forage and Grazinglands, 7(1), https:// dl.sciencesocieties.org/publications/fg/.../2009-123101-RS Online. 13 June 2014. doi: http://dx.doi.org/10.1094/FG-2009-1231-01-RS

26. Statistical Yearbook of the Republic of Croatia (2013): Croatian Bureau of Statistics, Zagreb, Croatia. http:// www.dzs.hr/Hrv_Eng/ljetopis/2013/sljh2013.pdf
27. Tucak, M., Popović, S., Čupić, T., Španić, V., Meglič, V. (2013): Variation in yield, forage quality and morphological traits of red clover (Trifolium pratense L.) breeding populations and cultivars. Zemdirbyste, 100(1): 63-70. doi: http://dx.doi.org/10.13080/z-a.2013.100.009

28. Vaseva, I., Akiscan, Y., Simova-Stoilova, L., Kostadinova, A., Nenkova, R., Anders, I., Feller, U., Demirevska, K. (2012): Antioxidant response to drought in red and white clover. Acta Physiologiae Plantarum, 34(5): 1689-1699. doi: http://dx.doi.org/10.1007/s11738-012-0964-4

29. Yates, S.A., Swain, M.T., Hegarty, M.J., Chernukin, I., Lowe, M., Allison, G.G., Ruttink, T., Abberton, M.T., Jenkins, G., Skøt, L. (2014): De novo assembly of red clover transcriptome based on RNA-Seq data provides insight into drought response, gene discovery and marker identification. BMC Genomics, 15: 453. doi: http://dx.doi.org/10.1186/1471-2164-15-453

\section{PROCJENA PROIZVODNOGA POTENCIJALA CRVENE DJETELINE (Trifolium pratense L.) U UVJETIMA OKOLIŠNOGA STRESA}

\section{SAŽETAK}

Globalne klimatske promjene uzrok su sve veće pojavnosti ekstremnih klimatskih pojava. Ciljevi ovog istraživanja bili su ispitati utjecaj klime (oborina $i$ temperature) na produktivnost populacija i sorti crvene djeteline različitoga genetičkoga podrijetla te identificirati materijale visokoga potencijala prinosa krme u uvjetima okolišnoga stresa. Tijekom dvije uzastopne godine (2012. - ekstremno sušni uvjeti, 2013. - vlažni vremenski uvjeti) na Poljoprivrednom institutu Osijek (Hrvatska) proučavane su dvadeset i tri populacije $i$ sorte crvene djeteline različitoga zemljopisnog podrijetla. Poljski je pokus postavljen po metodi slučajnoga bloknoga rasporeda u tri ponavljanja. Prinos zelene mase i suhe tvari te visina biljaka procijenjeni su u obje vegetacijske godine, dok je prinos sjemena utvrdivan samo u prvoj godini uzrasta. Rezultati provedenog istraživanja ukazuju na stabilnost $i$ adaptabilnost proučavanih sorti i populacija crvene djeteline u suhim ili vlažnim uvjetima proizvodnje. Hrvatske populacije (CD-3, TP-2, TP-7) i sorta Viva, srpska sorta K-17 i njemačka sorta Taifun pokazale su najveći potencijal prinosa krme u uvjetima oba okolišna stresa (izraziti sušni i vlažni uvjeti rasta) te predstavljaju vrijedan materijal koji će se koristiti u oplemenjivačkome programu crvene djeteline za poboljšanje tolerantnosti na abiotski stres.

Ključne riječi: crvena djetelina, sorta, populacija, klimatske promjene, okolišni stres

(Received on 9 September 2016; accepted on 7 December 2016 - Primljeno 9. rujna 2016.; prihvaćeno 7. listopada 2016.) 